\title{
Microfinance and Women Empowerment: A Case Study of Darjeeling District
}

\author{
Bhajan Chandra Barman*
}

\begin{abstract}
Micro finance in the form of Self-Help Group (SHG) Linkage model has been able to inspire hope in the lives of thousands of rural poor especially poor women by shifting them from debt-trap of informal credit sources to formal credit system. In this context the present study makes a modest attempt to examine that extent to which microfinance programme is effective in empowering rural women. A primary field survey has been carried out in Kharibari block of Darjeeling district to get the real picture. Survey method was applied and interview schedule has been used to collect relevant data from the respondents. Using tabular analysis and chi square test, results of this study indicate significant differences between SHGs women (i.e., those involved with SHG) and nonSHGs women regarding various economic, socio-cultural and political indicators of empowerment. It was also found that SHGs women have more active participation in various income generating activities. They earned more income, saved more money and at the same time owned more assets than non-SHGs women. The study also stresses the need of more loans to be expanded to rural poor women folk to enhance their economic solvency and empower them economically.
\end{abstract}

Key Words: Microfinance, Women Empowerment, Self-Help Group.

\subsection{Introduction}

The empowerment of women is one of the central issues in the process of development of all developing countries in the world. In the words of Pt. Jawaharlal Nehru "If you want to awaken a country, first awake women. If a woman is awakened a family is awakened and a family is awakened, a village is awakened thereby entire country is awakened." Since women's empowerment is the key to socio economic development of the community, bringing women into the mainstream of national development has been a major concern of government.

*Assistant Professor, Department of Economics, Netaji Nagar College, Kolkata. 
In India, when the trickle down effects of macroeconomic policies failed to resolve the problem of gender inequality, the government of India implemented different types of economic strategies, schemes and programmes for the betterment of the people. Starting with the Community Development Programme (CDP), the Government of India later shifted to several other programmes under Five Year Plans. Despite all these, several significant outcomes were visible in 1970s. Among these, the most important was that the highly neglected section of the society was women. Then onwards, the policy makers have focused their attention on shaping the socio-economic development of the women. However, history reveals that in many societies in India and the world, gender inequality has been a part and parcel of an accepted male-dominated culture. The traditional mentality of India assumed that the place of women is mainly concentrated to the household activities like kitchen work and upbringing of the children. Even after almost 67 years of India's Independence, women are still considered to be powerless and marginalised sections of the Indian society.

In order to bring the women at the same platform where the men are standing, the government of India is adopting many measures and formulating different types of plans and programmes. The government has also passed various legislations to safeguard Constitutional rights of women. These legislative measures include the Hindu Marriage Act (1955), The Hindu Succession Act (1956), Dowry Prohibition Act (1961), Medical Termination of Pregnancy Act (1971), Equal Remuneration Act (1976), and Child Marriage Restraint Act (1976). The Government of India adopted different programmes and policies like the Swa-Shakti Project, Women's Economic Programme (1982), Support to Training and Employment Programme to Women (1987), Hostel for working women, Rehabilitation of Marginalised Women, Education of Women like Social Education, Farmeres functional literacy Programme (1967), Non-formal Education (1978), National Literacy Mission (1988), Total Literacy Campaign (1991), Sarva Siksha Abhiyan (2000), and organisation of Self Help Groups, formation of cooperatives of women, etc. to empower the women. Apart from these, various welfare measures like the Support to Training for Employment Programme (1987), Mahila Samriddhi Yojana (1993), the Rashtriya Mahila Kosh (1992-93), Indira Mahila Yojana (1995), DWCRA Plan (1982), Balika Samriddhi Yojana (1997), formation of SHGs were introduced for the empowerment of women. In 2001 National Policy for the Empowerment of Women was introduced.

Despite the above measures, the fact is that, poverty, hunger and disease still remain widespread among the women and they continue to comprise the majority of the world's poorest people. Their position and status have been inferior to male members of 
the society. They have become a target of social, political and economic exploitation even after almost seven decades of India's independence.

Under these circumstances, through participation in microfinance programmes, women can join in the income generation activities which make them self-reliant and ultimately make them empowered which is very important for sustainable rural development and mainstreaming of women in India. The present study aims at establishing a standpoint of empowering women through microfinance in Darjeeling district of West Bengal.

\subsection{Women Empowerment: Conceptual framework}

As described by Kabeer (2001), there are two essential elements of women empowerment, i.e., process and agency. A process is defined as the series of events that produce gradual change. The process of women empowerment leads to expansion in their ability to have resources and to make strategic life choices. The agency element of women empowerment describes that women themselves are the significant actors in the process of change. It is the process through which choices are made.

Pillai (1995) defines women empowerment as an active, multidimensional process which enables women to realise their full identity and powers in all spheres of life. Stromquist (1995) wrote that the whole process of women empowerment requires the ability and active involvement of women themselves. According to Kumar and Paul (2007), "development agencies cannot claim to empower women rather they can provide appropriate external support and intervention which can, however, be important to foster and support the process of empowerment".

Batliwala (1994) identified three approaches to women's empowerment: the integrated development approach which focused on women's survival and livelihood needs; the economic development approach which aimed to strengthen women's economic position and the consciousness approach which organised women into collectives that address the source of oppression.

\subsection{Review of Literature}

In the present study, we mention some important studies which show the relation between microfinance and women empowerment. Hashemi et al. (1996) examine if women access to micro-credit has an effect on their well-being. Their results show that women access to micro-credit contributes enormously to their economic power. It contributes to the livelihood by an increase in asset holdings in their own names, to an increase in their exercise of purchasing power, and in their political and legal awareness 
as well as in composite empowerment index. They also find that access to credit was also associated with higher levels of mobility, political participation and involvement in major decision-making for particular credit organisations.

Holvoet (2005) analyses women's decision-making patterns with regard to loan borrowing. The results indicate that women who borrow directly from the banks always have fewer decision patterns, but when the loans are secured through women's groups and are combined with investment then a positive shift in decision-making patterns is noticed. Kabeer (2005) concludes that while access to financial services can and does make important contributions to the economic productivity and social wellbeing of poor women and their households, it does not "automatically" empower women - any more than do education, political quotas, access to wage work or any of the other interventions.

Schuler et al (1996) in their study suggest that group-based credit programs can reduce men's violence against women by making women's lives more public. Mayoux (1997) points out that the impact of microfinance on women varies from woman to woman. These differences arise due to the difference in productive activities or different background. Sometimes, microfinance mainly benefit the women who are already better off, whereas the poor women are either neglected by the microfinance programmes or are least able to benefit because of their low resource base, lack of skills and market contacts. However, poorer women can also be more free and motivated to use credit for production. The review of literature above clearly indicates that microfinance plays an important role in empowering poor women in rural areas.

3.0 Objectives of the study: The study was carried out with the following specific objectives:

i. To identify the factors related to empowerment of women.

ii. To measure the status of empowerment of rural women, both members and nonmembers in the selected area.

iii. To assess the role of the microfinance in empowering rural women in Darjeeling district of West Bengal.

\subsection{Hypotheses}

The following hypotheses will be tested for the study in respect of participants in microfinance through SHGs and non-participants. These hypotheses would investigate the role of microfinance in empowering women.

H1: There is a difference between participants and non-participants regarding their access to employment and income. 
H2: There is a difference between participants and non-participants regarding their access to and control over resources.

H3: There is a difference between participants and non-participants regarding their household financial decision making.

H4: There is a difference between participants and non-participants regarding their freedom and confidence of movement and visiting market for purchase of household goods.

H5: There is a difference between participants and non-participants regarding their awareness level.

H6: There is a difference between participants and non-participants regarding their education and skill level.

\subsection{Methodology}

\subsection{Selection of the study area}

Kharibari block under Darjeeling district of West Bengal has been selected for the purpose of the study. This block has been selected for the study because the SHGs under SGSY scheme in this block are functioning in a very successful manner. Secondly, among 12 blocks of Darjeeling district the highest number (173 SHGs up to March 2013) of SHGs that have taken up economic activities are from this block. Thirdly, so far no study has been undertaken in this block to assess the impact of microfinance through SHGs on empowerment of the rural poor women. As a result, we think that the study will be more representative by selecting the Kharibari block of Darjeeling district as the study area for our case study purpose.

\subsection{Sources of data}

The study is based on both primary and secondary data. Primary data was collected from a field survey in the Kharibari block. Secondary data was collected from various journals, articles, working papers, Block development office, and DRDC reports.

\subsection{Technique of data collection}

Purposive random sampling techniques have been used for the study. The study was conducted in the Kharibari block of Darjeeling district through a field survey. From the study block, we selected 100 women respondents who had the same socio-economic background. Among the 100 selected women, 50 women have been taken from SHGs which have taken up economic activities and engaged in the programme for eight years or more at a stretch and another 50 women are non-SHG members. With the help of 
prepared questionnaires and interview schedules, the information and relevant data were collected.

We have used simple statistical tools like percentage, frequency distribution, Chi-square test for the analysis of the data.

\subsection{Limitations of the study}

The study has the following limitations:

i. The study applies to a selected block in the Darjeeling district of West Bengal and not anywhere else. Most of the respondents are illiterates and so collection of the data was a little difficult.

ii. The data was collected only from those who engaged in income generating activities.

\subsection{Impact of Microfinance on Women Empowerment: Results and Analysis}

In this study, an empowered woman is considered to be one who has made her life better by having access to and utilisation of resources provided by microfinance programme. She also participates in the household decision-making. She shows selfconfidence and also participates in the democratic institutions in the rural area. She has general awareness of the existing social, economic and political environment. Table 1 shows the indicators of women empowerment used in the study.

Table 1: Indicators of Women Empowerment

\begin{tabular}{|l|l|}
\hline Domain & Indicators \\
\hline Empowerment & (i) Women access to employment \\
& $\begin{array}{l}\text { (ii) Women contribution to household income } \\
\text { (iii)Access to and control over household resources } \\
\text { (iv) Participation in household financial decision-making }\end{array}$ \\
\hline $\begin{array}{l}\text { 2. Socio-cultural and } \\
\text { Familial Empowerment }\end{array}$ & $\begin{array}{l}\text { (i) Women freedom and confidence of movement } \\
\text { (ii) Visiting market for purchase of household goods }\end{array}$ \\
\hline 3. Political Empowerment & $\begin{array}{l}\text { (ii) Awareness of local, state level and national polity } \\
\text { (ii) Participation in panchayat meetings }\end{array}$ \\
\hline $\begin{array}{l}\text { 4. Education, and Skill } \\
\text { Empowerment }\end{array}$ & $\begin{array}{l}\text { (i) Education and ability to read and write } \\
\text { (ii) Understanding of basic banking process }\end{array}$ \\
\hline
\end{tabular}




\subsection{Economic empowerment}

Microfinance through SHGs has linked rural poor women with formal credit delivery system, provided micro-loans and has encouraged them to start microenterprises. This programme has helped in increasing self-employment as well as income of the participants and helped them to become economically more empowered than nonparticipants.

\section{(i) Women's access to employment}

The study shows that the microfinance programme has helped the participants in increasing employment, particularly self-employment. Table 2 shows that the participants are employed for more number of days as compared to the non-participants. The participants are employed for 160 person-days per annum, whereas the nonparticipants are employed only for 113 person-days per annum. Therefore, the programme participants have more access to employment as compared to the nonparticipants.

Table 2: Women's Access to Employment

\begin{tabular}{|l|c|c|c|c|c|c|}
\hline \multirow{2}{*}{ Activities } & \multicolumn{3}{|c|}{ SHGs Members } & \multicolumn{2}{c|}{ Non-SHGs Members } \\
\cline { 2 - 7 } & $\begin{array}{c}\text { No. of } \\
\text { respondents }\end{array}$ & $\begin{array}{c}\text { Total } \\
\text { employment }\end{array}$ & $\begin{array}{c}\text { Mean } \\
\text { employment }\end{array}$ & $\begin{array}{c}\text { No. of } \\
\text { Respondents }\end{array}$ & $\begin{array}{c}\text { Total } \\
\text { employment }\end{array}$ & $\begin{array}{c}\text { Mean } \\
\text { employment }\end{array}$ \\
\hline Farming & 15 & 3000 & 200 & 10 & 1200 & 120 \\
\hline $\begin{array}{l}\text { Agricultural } \\
\text { Labourers }\end{array}$ & 6 & 780 & 130 & 21 & 2520 & 120 \\
\hline $\begin{array}{l}\text { Animal } \\
\text { Husbandry }\end{array}$ & 10 & 1200 & 120 & 6 & 540 & 90 \\
\hline Handicrafts & 10 & 1200 & 120 & 8 & 480 & 60 \\
\hline $\begin{array}{l}\text { Petty } \\
\text { Business }\end{array}$ & 9 & 1800 & 200 & 5 & 900 & 180 \\
\hline Total & $\mathbf{5 0}$ & $\mathbf{7 9 8 0}$ & $\mathbf{1 5 9 . 6}$ & $\mathbf{5 0}$ & $\mathbf{5 6 4 0}$ & $\mathbf{1 1 2 . 8}$ \\
\hline
\end{tabular}

Source: Field survey

\section{(ii) Women contribution to household income}

Microfinance programme has helped the women participants to increase their contribution to the household income. Table 3 shows that average income of the participants is Rs. 817 per month as compared to Rs. 595 of the non-participants. As a result, microfinance programme has generated additional income of Rs. 222 per month for the programme participants. 
Table 3: Women contribution to household annual income

(Amount in Rs.)

\begin{tabular}{|l|c|c|c|c|c|c|}
\hline \multirow{2}{*}{ Activities } & \multicolumn{3}{|c|}{ SHGs Members } & \multicolumn{3}{c|}{ Non-SHGs Members } \\
\cline { 2 - 7 } & $\begin{array}{c}\text { No. of } \\
\text { Respondents }\end{array}$ & $\begin{array}{c}\text { Total } \\
\text { Income }\end{array}$ & $\begin{array}{c}\text { Average } \\
\text { Income }\end{array}$ & $\begin{array}{c}\text { No. of } \\
\text { Respondents }\end{array}$ & $\begin{array}{c}\text { Total } \\
\text { Income }\end{array}$ & $\begin{array}{c}\text { Men } \\
\text { employment }\end{array}$ \\
\hline Farming & 15 & 90000 & 6000 & 10 & 30000 & 3000 \\
\hline $\begin{array}{l}\text { Agricultural } \\
\text { Labourers }\end{array}$ & 6 & 73000 & 12167 & 21 & 252000 & 12000 \\
\hline $\begin{array}{l}\text { Animal } \\
\text { Husbandry }\end{array}$ & 10 & 125000 & 12500 & 6 & 12000 & 2000 \\
\hline Handicrafts & 10 & 40000 & 4000 & 8 & 18000 & 2250 \\
\hline $\begin{array}{l}\text { Petty } \\
\text { Business }\end{array}$ & 9 & 162000 & 18000 & 5 & 45000 & 9000 \\
\hline Total & $\mathbf{5 0}$ & $\mathbf{4 9 0 0 0 0}$ & $\mathbf{9 8 0 0}$ & $\mathbf{5 0}$ & $\mathbf{3 5 7 0 0 0}$ & $\mathbf{7 1 4 0}$ \\
\hline
\end{tabular}

Source: Field survey

\section{(iii) Access to and control over family resources}

Access to and control over household resources has been considered as the possession of house, land, gold and jewellery, etc. If a woman owns the house/land, she gets more respect and feels more control over the family. The possession of gold and jewellery leads to economic security. Microfinance programme increases the economic prospectus of the participants, which helps them to have access to and control over the household economic resources Table 4 shows that just 4 percent of the participants and 2 percent of the non-participants own house in their name and just 6 percent of the participants and 2 percent of the non-participants own land.

The respondents were also asked about their possession of gold and jewellery .It is found that 70 percent of the participants and 24 percent of the non-participants possess some gold. One of the reasons of large number of the participants having possession of gold may be their economic prosperity. Chi-square $(\chi 2)$ test shows significant differences among the participants and non-participants regarding the possession of gold.

\section{(iv) Role of women in household financial decision-making}

Women involved in the household financial decision-making are definitely more empowered because generally male members of the family dominate in financial decision-making. The respondents were asked about their independence and contribution in making financial decisions like budget allocation, when to get a loan, amount and source of loan, buying and selling of household durables etc. Table 5 shows the role of women in the household financial decision-making. 
Table 4: Access to and Control over Family Resources

\begin{tabular}{|l|l|c|c|c|c|}
\hline \multicolumn{2}{|c|}{ Indicator } & \multicolumn{2}{c|}{ SHG members } & \multicolumn{2}{c|}{ Non-SHG members } \\
\cline { 3 - 6 } \multicolumn{2}{|c|}{} & No. & Percentage & No. & Percentage \\
\hline \multirow{3}{*}{ Ownership of house } & Yes & 2 & 4.00 & 1 & 2.00 \\
\cline { 2 - 6 } & No & 48 & 96.00 & 49 & 98.00 \\
\hline \multirow{3}{*}{ Ownership of Land } & Yes & 3 & 6.00 & 1 & 2.00 \\
\cline { 2 - 6 } & No & 47 & 100.00 & 49 & 98.00 \\
\hline \multirow{2}{*}{ Possession of gold } & Yes & 35 & 70.00 & 12 & 24.00 \\
\cline { 2 - 6 } & No & 15 & 30.00 & 38 & 76.00 \\
\hline
\end{tabular}

Source: Field survey

Note: Chi-square $(\chi 2)=24.42$. Table values at $5 \%$ and $1 \%$ with 1 degree of freedom (d.f.) are 3.84 and 6.63 respectively

Table 5: Role of Women in Household Financial Decision-Making

\begin{tabular}{|l|c|c|c|c|}
\hline \multirow{2}{*}{$\begin{array}{l}\text { Financial Decision- } \\
\text { making }\end{array}$} & \multicolumn{2}{|c|}{ SHG members } & \multicolumn{2}{c|}{ Non-SHG members } \\
\cline { 2 - 5 } & No. & Percentage & No. & Percentage \\
\hline Self - dominate & 13 & 26.00 & 4 & 8.00 \\
\hline Husband -dominate & 3 & 6.00 & 5 & 10.00 \\
\hline $\begin{array}{l}\text { Jointly by self } \\
\text { \&husband }\end{array}$ & 33 & 66.00 & 32 & 64.00 \\
\hline $\begin{array}{l}\text { Other members } \\
\text { dominate }\end{array}$ & 1 & 2.00 & 9 & 18.00 \\
\hline Total & $\mathbf{5 0}$ & $\mathbf{1 0 0 . 0 0}$ & $\mathbf{5 0}$ & $\mathbf{1 0 0 . 0 0}$ \\
\hline
\end{tabular}

Source: Field survey

Note: Chi-square $(\chi 2)=11.66$. Table values at $5 \%$ and $1 \%$ with 3 d.f. $=7.81$ and 11.3 respectively.

Table 5 shows that 26 percent of the participants and just 8 percent of the nonparticipants dominate in household financial decisions. However, in a majority of cases, both husband and wife jointly take the household decisions. 66 percent of the participants and 64 percent of the non-participant women take financial decisions jointly with their husbands. The Chi-square $\left(\chi^{2}\right)$ test also shows that the difference between participants and non-participants regarding their role in household financial decisionmaking is significant at 5 percent and 1 percent level of significance.

\subsection{Socio-cultural and familial empowerment}

Microfinance programme gives women an opportunity to come out of the four walls of their houses and meet other members of the society, which leads to their sociocultural and familial empowerment. 


\section{(i) Women's freedom and confidence of movement}

SHG activities encourage and offer an opportunity to their members to visit other places. Exposure of the members increases their confidence in travelling to other places. Table 6 shows the confidence of SHG members to visit a nearest town. It is observed that 80 percent participants are confident to visit a nearest town as compared to 64 percent of non-participants. It is clear from the table that participants of the programme are more confident in visiting nearest towns than non-participants. Chi-square test shows very significant differences among participants and nonparticipants regarding their confidence in travelling to a town.

Table 6: Women's Freedom and Confidence of Movement

\begin{tabular}{|l|l|c|c|c|c|}
\hline \multicolumn{2}{|l|}{ Level of confidence } & \multicolumn{2}{c|}{ SHG members } & \multicolumn{2}{c|}{ Non-SHG members } \\
\cline { 3 - 6 } \multicolumn{2}{l|}{} & No. & Percentage & No. & Percentage \\
\hline \multirow{2}{*}{\begin{tabular}{l} 
Travelling \\
to a nearest \\
\multirow{2}{*}{$\begin{array}{l}\text { town } \\
\end{array}$}
\end{tabular}} & More confident & 40 & 80.00 & 32 & 64.00 \\
\cline { 2 - 6 } & Less confident & 8 & 16.00 & 10 & 20.00 \\
\cline { 2 - 6 } & Can't go & 2 & 4.00 & 8 & 16.00 \\
\cline { 2 - 6 } & Total & $\mathbf{5 0}$ & $\mathbf{1 0 0 . 0 0}$ & $\mathbf{5 0}$ & $\mathbf{1 0 0 . 0 0}$ \\
\hline
\end{tabular}

Source: Field survey

Note: Chi-sq. $\left(\chi^{2}\right)=17.48$ Table values at $5 \%$ and $1 \%$ with 2 d.f. $=5.99 \& 9.21$ respectively.

\section{(ii) Visiting market for purchase of household goods}

Visiting market increases the ability of a woman in various ways such as selfconfidence, decision-making capacity, ability to make calculations, motivation, social relations and knowledge etc. Table 7 shows that 84 percent of the participants as compared to just 60 percent of the non-participants are more confident to visit the market for the purchase of goods. Chi-square test shows that these differences are significant at 5 percent level of significance.

Table 7: Confidence to Visit Market

\begin{tabular}{|l|l|c|c|c|c|}
\hline \multirow{2}{*}{ Level of confidence } & \multicolumn{2}{|c|}{ SHG members } & \multicolumn{2}{c|}{ Non-SHG members } \\
\cline { 3 - 6 } \multicolumn{2}{|c|}{} & No. & Percentage & No. & Percentage \\
\hline \multirow{2}{*}{$\begin{array}{l}\text { Travelling } \\
\text { to the market for } \\
\text { purchases }\end{array}$} & More confident & 42 & 84.00 & 30 & 60.00 \\
\cline { 2 - 6 } & Less confident & 5 & 10.00 & 12 & 24.00 \\
\cline { 2 - 6 } & Not confident & 3 & 6.00 & 8 & 16.00 \\
\cline { 2 - 6 } & Total & $\mathbf{5 0}$ & $\mathbf{1 0 0 . 0 0}$ & $\mathbf{5 0}$ & $\mathbf{1 0 0 . 0 0}$ \\
\hline
\end{tabular}

Source: Field survey

Note: Chi-sq. $(\chi 2)=7.16$. Table value at $5 \%$ with 2 d.f. $=5.99$. 


\subsection{Political Empowerment}

It has been observed that microfinance programme has empowered the women participants socio-economically as well as politically. We attempt to understand their level of political empowerment using the following parameters.

\section{(i) Awareness of Local, State and National level}

In order to find the awareness of the respondents about the local, state and national affairs, some questions like name of their village Panchayat, Chief Minister of the state and Prime Minister of India were asked. An attempt was also made to know whether they recognise all these personalities. The results are shown in Table 8.

Table 8: Awareness of Local, State and National Level

\begin{tabular}{|l|l|c|c|c|c|}
\hline \multicolumn{2}{|c|}{ Indicator } & \multicolumn{2}{c|}{ SHG members } & \multicolumn{2}{c|}{ Non-SHG members } \\
\cline { 3 - 6 } \multicolumn{2}{l|}{} & No. & Percentage & No. & Percentage \\
\hline $\begin{array}{l}\text { Know the name } \\
\text { of village Panchayat and } \\
\text { recognise the same }\end{array}$ & Yes & 48 & 96.00 & 45 & 84.00 \\
\cline { 2 - 6 } & No & 2 & 4.00 & 5 & 16.00 \\
\hline $\begin{array}{l}\text { Know the names of } \\
\text { Chief Minister }\end{array}$ & Yes & 28 & 56.00 & 22 & 44.00 \\
\cline { 2 - 6 } & No & 22 & 44.00 & 28 & 56.00 \\
\hline $\begin{array}{l}\text { Know the name of } \\
\text { Prime Minister }\end{array}$ & Yes & 17 & 34.00 & 7 & 14.00 \\
\cline { 2 - 6 } & No & 33 & 66.00 & 43 & 86.00 \\
\hline Total & & $\mathbf{5 0}$ & $\mathbf{1 0 0 . 0 0}$ & $\mathbf{5 0}$ & $\mathbf{1 0 0 . 0 0}$ \\
\hline
\end{tabular}

Source: Field survey

Note: Chi-square $(\chi 2)=1.36,1.44$ and 11.58 . Table values at $5 \%$ and $1 \%$ with 1 d.f. $=3.84$ and 6.63 respectively.

It was observed that almost all the participants and non-participants are aware about the name of their village Panchayat and are able to recognise the same. However, when participants were asked about the name of the Chief Minister of West Bengal and Prime Minister of India, 56 percent and 34 percent of the participants responded positively as compared to 44 and 14 percent of non-participants respectively. Chi-square test shows insignificant differences among the participants and non-participants regarding their knowledge of local and state level polity but the difference regarding their awareness of the national polity is very significant. 


\section{(ii) Participation in Panchayat meetings}

The participation of women in Panchayat meetings indicates their selfconfidence, awareness and progressiveness. The respondents were asked whether they attend and participate in such meetings or not. 76 percent of the participants responded positively as compared to 36 percent of the non-participants (Table 9). Chi-square test shows that these differences are significant at 5 percent level of significance.

Table 9: Participation in Panchayat Meetings

\begin{tabular}{|l|c|c|c|c|c|}
\hline \multicolumn{2}{|c|}{ Indicator } & \multicolumn{2}{|c|}{ SHG members } & \multicolumn{2}{c|}{ Non-SHG members } \\
\cline { 3 - 6 } \multicolumn{2}{|c|}{} & No. & Percentage & No. & Percentage \\
\hline \multirow{2}{*}{$\begin{array}{l}\text { Participation in panchayat } \\
\text { meetings }\end{array}$} & Yes & 38 & 76.00 & 18 & 36.00 \\
\cline { 2 - 6 } & No & 12 & 24.00 & 32 & 64.00 \\
\cline { 2 - 6 } & Total & $\mathbf{5 0}$ & $\mathbf{1 0 0 . 0 0}$ & $\mathbf{5 0}$ & $\mathbf{1 0 0 . 0 0}$ \\
\hline
\end{tabular}

Source: Field survey

Note: Chi-square $(\chi 2)=16.24$. Table values at $5 \%$ and $1 \%$ with 1 d.f. $=3.84$ and 6.63 respectively.

\subsection{Education and Skill Empowerment}

The education and skill empowerment indicators that have been used for analysis include ability to read and write; and ability to understand and perform basic banking operations.

\section{(i) Education and ability to read and write}

Education is the important factor for women empowerment. Table 10 shows that 32 percent of the participants and 40 percent of the non-participants are illiterate. 10 percent of the illiterate participants and 30 percent of the non-participants are not able to read numbers and write even their name. But 22 percent of the illiterate participants and 10 percent of the non-participants are able to read numbers and write their name. Therefore, it can be seen that though illiterate, the programme participants are more able to read and write as compared to the illiterate non-participants. The level of education of participants and non-participants is also compared. It is found that 22 percent of the participants and 28 percent of the non-participants are educated up to primary level, 30 percent of the participants and 20 percent of the non-participants are educated up to Class V-VIII and12 percent of the participants and 10 percent of the non-participants are educated up to class IX-XII level. The Chi-square $(\chi 2)$ test shows insignificant difference between the participants and non-participants regarding their education and ability to read and write. 
Table 10: Education and Ability to Read and Write

\begin{tabular}{|l|c|c|c|c|}
\hline \multirow{2}{*}{ Status of Education } & \multicolumn{2}{|c|}{ SHG members } & \multicolumn{2}{c|}{ Non-SHG members } \\
\cline { 2 - 5 } & No. & Percentage & No. & Percentage \\
\hline Illiterate & 5 & 10.00 & 15 & 30.00 \\
\hline Only read and write & 11 & 22.00 & 5 & 10.00 \\
\hline Class I-IV & 11 & 22.00 & 14 & 28.00 \\
\hline Class V-VIII & 15 & 30.00 & 10 & 20.00 \\
\hline Class IX-XII & 6 & 12.00 & 5 & 10.00 \\
\hline Graduate & 2 & 4.00 & 1 & 2.00 \\
\hline Total & $\mathbf{5 0}$ & $\mathbf{1 0 0 . 0 0}$ & $\mathbf{5 0}$ & $\mathbf{1 0 0 . 0 0}$ \\
\hline
\end{tabular}

Source: Field survey

Note: Chi-square $(\chi 2)=1.36$. Table values at $5 \%$ and $1 \%$ with 5 d.f. $=11.07$ and 15.09 respectively.

\section{(ii) Ability to understand and perform basic banking operations}

Microfinance programme participants visit banks to deposit the group savings, for getting loans and for repaying the loan instalments. It enables them to perform the basic banking operations such as opening an account, filling a bank form, understanding pass-book entries etc. Table 11 shows that 56 percent of the participants and 22 percent of the non-participants face no difficulty in performing basic banking operations.

Table 11: Ability to Understand and perform Basic Banking Operations

\begin{tabular}{|l|c|c|c|c|}
\hline \multirow{2}{*}{ Status of Education } & \multicolumn{2}{|c|}{ SHG members } & \multicolumn{2}{c|}{ Non-SHG members } \\
\cline { 2 - 5 } & No. & Percentage & No. & Percentage \\
\hline No difficulty & 28 & 56.00 & 11 & 22.00 \\
\hline Some difficulty & 13 & 26.00 & 20 & 40.00 \\
\hline Lot of difficulty & 9 & 18.00 & 19 & 38.00 \\
\hline Total & $\mathbf{5 0}$ & $\mathbf{1 0 0 . 0 0}$ & $\mathbf{5 0}$ & $\mathbf{1 0 0 . 0 0}$ \\
\hline
\end{tabular}

Source: Field survey

Note: Chi-square $(\chi 2)=13.16$. Table values at $5 \%$ and $1 \%$ with 2 d.f. $=5.99$ and 9.21 respectively.

However, 18 percent of the participants and 38 percent of the non-participants face difficulties or cannot perform these banking functions. Chi-square test also shows significant differences among the participants and non-participants. 
106 | PRAGATI: Journal of Indian Economy, Vol. 2, Issue 1

\subsection{Conclusion}

Based on the results mentioned in this study, it can be concluded that microfinance has played an important role for empowering rural poor women in Darjeeling district of West Bengal. The results of this study indicated significant differences between SHGs women and non-SHGs women regarding all these economic, socio-cultural and political indicators of empowerment. In all the cases, SHGs women were more economically empowered than those of non-SHGs women. It was also found that SHGs women had more active participation in various income generating activities. The study also revealed that the SHGs women received more microcredit and utilised this for conducting more income generating activities than control group. They earned more income, saved more money and at the same time owned more assets than nonSHGs women. The study stresses the need of more loans to be granted to rural poor women folk by different government organisations and non-governments organisations (NGOs) which would ultimately enhance their economic solvency and empower them economically. This would indeed be helpful for the upliftment of the rural poor women socio-economically.

\section{References}

Batliwala S. (1994). The meaning of women's empowerment: New concepts from action. In Gita Sen, Adrienne Germain and Lincoln C. Chen eds. Population Policies Reconsidered: Health, Empowerment and Right. Cambridge, Harvard University Press.

Hashemi, S.M., Schuler, S.R., \& Riley, A.P. (1996). Rural credit programs and women's empowerment in Bangladesh. World Development, 24 (4): 635-653.

Holvoet, N. (2005). The impact of microfinance on decision-making agency: Evidence from South India. Development and Change, 36 (1): 75-102.

Kabeer, N. (2001). Conflict over credit: Re-evaluating the empowerment potential of loans to women in rural Bangladesh. World Development, 29(1): 63-84.

Kabeer, N. (2005), Is micro finance a magic bullet for women's empowerment? Analysis of findings from South Asia. Economic and Political Weekly October 29, XL(44-45): 4709-18. 
Kumar, P. \& Paul, T. (2007). Empowerment of women: Concept, policy approach and implications. Paper Presented at a Seminar on Gender Issues and Empowerment of Women, Indian Statistical Institute, Kolkata, 1-2 February.

Mahmud S. (2003). Actually how empowering is micro credit? Development and Change, 34(4):577-605.

Mayoux L. (1997). The magic ingredient? Microfinance and women's empowerment. A Briefing Paper prepared for the Micro Credit Summit, Washington.

Pillai, J.K. (1995). Women and Empowerment. Gyan Publishing House: New Delhi.

Rahman A. (1999). Women and microcredit in Rural Bangladesh: An anthropological study of Grameen Bank Lending, Boulder, West view Press: Colorado, USA.

Schuler, S.R. \& Hashemi, S. M. (1994). Credit programs, women's empowerment, and contraceptive use in rural Bangladesh. Studies in Family Planning, 25(2), 65-76.

Stromquist, N. P. (1995). The theoretical and practical bases for empowerment. In Carolyn Medel-Anonuevo (ed.), Women, Education and Empowerment: Pathways Towards Autonomy, United Nations Educational, Scientific and Cultural Organization (UNESCO), Hamburg: Germany. 